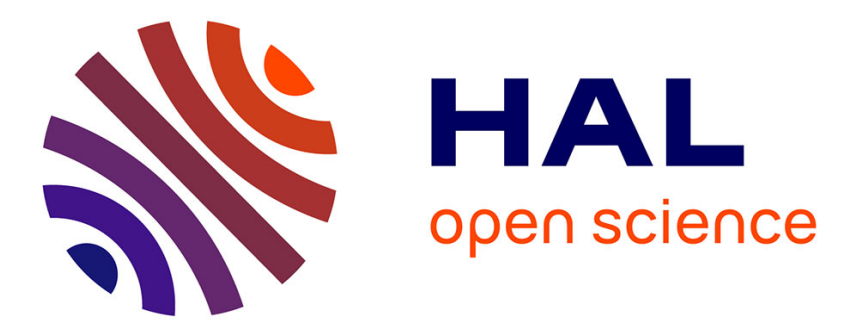

\title{
Joint hypermobility syndrome: problems that require psychological intervention
}

\author{
C. Baeza-Velasco, M. C. Gély-Nargeot, A. Bulbena Vilarrasa, J. F. Bravo
}

\section{To cite this version:}

C. Baeza-Velasco, M. C. Gély-Nargeot, A. Bulbena Vilarrasa, J. F. Bravo. Joint hypermobility syndrome: problems that require psychological intervention. Rheumatology International, 2011, 31 (9), pp.1131-1136. 10.1007/s00296-011-1839-5 . hal-00676227

\section{HAL Id: hal-00676227 \\ https://hal.science/hal-00676227}

Submitted on 4 Mar 2012

HAL is a multi-disciplinary open access archive for the deposit and dissemination of scientific research documents, whether they are published or not. The documents may come from teaching and research institutions in France or abroad, or from public or private research centers.
L'archive ouverte pluridisciplinaire HAL, est destinée au dépôt et à la diffusion de documents scientifiques de niveau recherche, publiés ou non, émanant des établissements d'enseignement et de recherche français ou étrangers, des laboratoires publics ou privés. 


\title{
Joint Hypermobility Syndrome: problems that require psychological intervention
}

\author{
C. Baeza-Velasco \\ Department of Psychiatry and Legal Medicine, University Autonomous of Barcelona. \\ M.C. Gély-Nargeot \\ Laboratory Epsylon, University Paul Valéry Montpellier 3. \\ A. Bulbena-Vilarrasa \\ Department of Psychiatry and Legal Medicine, University Autonomous of Barcelona. \\ J.F. Bravo \\ Faculty of Medicine, University of Chile.
}

\begin{abstract}
Joint Hypermobility Syndrome (JHS), also known as Ehlers-Danlos III, is an inherited disorder of connective tissue, characterised by an exceptional increase in the joint's mobility and the presence of musculoskeletal and other symptoms. It is a benign syndrome if compared with the other types of Ehlers-Danlos, but it can become disabling particularly because it is a significant source of pain and distress. The purpose of this work is to describe some common problems in JHS that render psychological intervention in their overall management relevant. Chronic pain, associated psychopathological factors such as anxiety, depression and somatosensory amplification, and problems arising from a lack of recognition and knowledge of the syndrome, are frequent among those affected, having a negative impact on their quality of life. We emphasise the relevance of addressing JHS from a biopsychosocial approach.
\end{abstract}

Key words: joint hypermobility syndrome, psychological treatment, chronic pain

Correspondence concerning this article should be addressed to C. Baeza-Velasco, E-mail: c.baezavelasco@gmail.com 


\section{Joint hypermobility (JH) and Joint Hypermobility Syndrome (JHS)}

$\mathrm{JH}$ is a common feature of heritable disorders of connective tissue (HDCT), a group of genetic disorders affecting the matrix of proteins of connective tissue and that typically include Ehlers-Danlos syndrome, Marfan syndrome and Osteogenesis Imperfecta [1].

Hypermobile people can move one or multiple joints in such a wide range of movement that it seems unusual to the rest of the population. $\mathrm{JH}$ is not necessarily a problem; it is commonly seen in healthy individuals who do not have complaints [2]. Some people even consider it to be an advantageous condition, because it increases flexibility which can be useful in some sports or artistic activities. The medical problem arises when $\mathrm{JH}$ is accompanied by musculoskeletal symptoms, such as arthralgias, subluxation or dislocation of joints, tendonitis, bursitis, abnormalities of the skin, myopia, and other nonarticular manifestations, especially psychiatric symptoms such as anxiety and phobic states $[3,4]$. In the absence of systemic rheumatologic disease, such as Rheumatoid Arthritis or Systemic Lupus, these cases are known as JHS. Symptoms occur because the altered collagen in the connective tissues is more flexible and weak, and therefore is more likely to suffer trauma [4].

JHS is considered a benign syndrome because it has a better prognosis than other inherited HDCT. It is even considered a form frustre of the other types of HDCT [5] and it is also more frequent in the population than the other types. The prevalence of JHS is very high in Hispanic countries. In Chile, Bravo and Wolff [6] found a prevalence of 39\%, and in Spain, JHS constitutes $25 \%$ of rheumatological consultations [7]. In spite of its high frequency, there is a lack of diagnosis of JHS [6] with a general lack of knowledge among health professionals and patients.

Because of the ubiquitous nature of connective tissue proteins, the possible consequences of tissue trauma are innumerable. No two patients with JHS will present in an identical fashion. As a result every patient will need a treatment plan tailored to his or her particular set of problems [8]. Treatment modalities include patient education, activity modification, stretching and strengthening exercises for the affected joint and osteopathic manipulative treatment [2]. Thus, although there is no specific treatment that restores the condition, patients can be helped in various ways from a multidisciplinary approach.

The aim of this work is to describe some frequent symptoms and situations in JHS that make psychological intervention in their overall management relevant. Through a review of the literature related to JHS, we have identified some common problems that require attention 
from a psychological/psychiatric point of view. They are presented grouped into 3 subject matters: chronic pain, psychopathological factors associated with JHS, and problems arising from a lack of recognition and knowledge of JHS.

We hope that this article review can serve as a reference for physicians, when establishing an integrated biopsychosocial therapy, and for psychologists who may take these factors into account when planning treatment protocols tailored to JHS patients, such as cognitive-behavioural therapy protocols and psychoeducational programmes.

\section{Chronic Pain}

The main complaint of JHS patients is pain. Above all it is the overriding chronic pain in joints, muscles and ligaments, which arises from an inherent predisposition to the effects of everyday trauma [9]. It is a chronic pain that significantly alters the quality of life of those affected, by reducing sleep, social and working relations, sexual functions, physical activities and recreation [10]. As a result, patients may experience psychosocial problems, which in many cases severely affect their healthy functioning. Therefore, it is not surprising that $29 \%$ of those suffering from chronic pain, suffer from depression [11].

Conventional approaches for pain-relief such as analgesics, non-steroidal antiinflammatory drugs (NSAIDs), psychotropic medication, physiotherapy and surgery are often ineffective [9]. In this regard, alternative methods are needed in order to cope with chronic pain in JHS.

Despite the fact that pain is currently considered to be a multidimensional phenomenon [12], there are few cases where pain is treated with a genuine multidisciplinary approach [13]. The experience of the INPUT unit at St. Thomas Hospital in London is noteworthy. INPUT manages the pain from a biopsychosocial approach. In a pilot study with 36 Caucasian patients from the INPUT unit, it was found that $19.4 \%$ of these patients had JH, and $41.6 \%$ of the patients reported a family history of hypermobility, or were able to perform contortions when younger [14]. According to Harding [15] approximately 40\% of chronic pain patients at the INPUT unit, could be deemed as having past or present joint hypermobility, which highlights the potential number of patients with hypermobility within the chronic pain population. 
Some common difficulties that chronic pain sufferers have are: patterns of overactivity- underactivity cycles, use of a tissue damage model, a lack of useful information and unhelpful beliefs or cognitive styles [15]. In this regard, Cognitive-Behavioural Treatment (CBT) for pain management is based on a cognitive-behavioural model of pain, the hallmark of which is the notion that pain is a complex experience that is not only influenced by its underlying pathophysiology, but also by an individuals' cognition, affect, and behaviour [16].

From a cognitive point of view, patients suffering from chronic pain develop a system of specific beliefs about their pain [17] which can lead to increased disability or have an effect on mood. Harding [15] relates some examples of JHS patients' beliefs about pain: "Pain means damage, if doing something hurts I should avoid it", "I'll get worse as I get older, it's hopeless, maybe I should just accept I'll end up in a wheelchair", "I've got wear and tear, better not use my joints or they'll wear out even quicker", "I need to rest more, if you feel tired it means you've been doing too much", "If the pain gets any worse I'll go mad, I'm desperate, surely no-one could be expected to cope with this", "My pain is a sign of whether I am better, I won't be better until my pain has gone". These commentaries clearly illustrate some common patterns of negative thinking such as catastrophising, filtering, personalising, generalising and polarising. They directly influence mood and cause patients to react negatively. Chronic pain patients often have negative expectations about their own ability and responsibility to exercise any form of control over their pain, and see themselves as disabled. Such a maladaptive evaluation of their situation and personal effectiveness enhances the experience of demoralisation, inactivity and hyperactivity of the nociceptive stimulation [18].

More debilitating than the pain itself is the fear of pain [19]. This fear leads to avoidance behaviours that create a vicious circle which contribute to worsening the scenario; a person who has pain, especially on movement, tends to avoid doing things that provoke their symptoms. These avoidant behaviours generate an excess of rest and a lower level of functional activity, with consequent deficiencies in adaptive skills repertoires in various areas due to lack of application [20].

CBT is not intended to eliminate the pain, but rather to help patients manage pain and its negative consequences [21]. As in any therapeutic process, it is necessary to explore motivation and the expectations of patients regarding a psychological intervention. The medical model is well internalised in the population, and often patients are used to treatments in which the attitude is rather passive as occurs when following a pharmacological treatment only; the effect of the drug is expected and the only collaboration from the patient is that they 
self-administer the prescribed doses and attend medical appointments [22]. In this regard, CBT is a structured intervention that demands active participation from participants and joins efforts and resources at different levels: time, because even if the treatment has a limited duration and usually is brief, a series of sessions must be attended. The economic cost, and overall performance of specific tasks to achieve the proposed objectives. So it is very important to emphasise and clarify that the relationship between patient and therapist is based on understanding and collaboration.

CBT offers the best prospect of recovery and rehabilitation for chronic pain in hypermobility patients [23]. The experience of a chronic pain management programme, specifically designed for people with JHS at the university College London Hospitals, confirms the benefits of CBT in these patients. The programme, based on a multidisciplinary team, emphasises the importance of recovering lost functions, improving mood and selfefficacy, pacing activities, reducing (analgesic) medication. Pilot data collected from 12 participants with JHS at 1 month, 3 months, and 12 months post-programme, showed demonstrable improvements in group-average scores of mood and self-efficacy were found with notable reductions in pain-related "catastrophising" and disability, and fear of injury or re-injury [24].

\section{Psychopathological factors associated with JHS}

One of the many interesting aspects that arise in the study of JHS, is the relation that this syndrome, in principle the field of musculoskeletal medicine, presents with other disciplines like psychiatry and psychology. Bulbena et al. [3] found that around 70\% of rheumatological patients with joint hypermobility had had some kind of anxiety disorders earlier in their lives, meaning they were ten times more likely to suffer from anxiety than patients without joint hypermobility. Subsequent studies have found solid evidence of the relationship between joint hypermobility and anxiety states; from panic attack to worrier temperament, high levels of sub-clinical anxiety and authentic phobias [5, 25-29].

A cytogenetic anomaly common to both joint hypermobility and anxiety disorders has been described [30] constituting the first evidence of this possible shared biological foundation. However, subsequent studies have not confirmed this finding [31,32]. What is certain is that in clinical practice, the association between both phenomena is clear. Some authors such as Bulbena et al., talk of anxiety disorders as part of nonarticular manifestations of JHS. In a study in the Chilean population [29], a group of variables which distinguish the 
whole group of cases (JHS) from the control group was identified, with the following both organic and psychopathological variables resulting significant: scoliosis, double-jointedness, headache, asthma, consumption of anxiolytic and antidepressants and antecedents of panic disorder without agoraphobia.

The possibility of identifying patients who are susceptible to suffering from an anxiety disorder through exploring signs and symptoms associated with JHS, is a beneficial contribution of this research line, especially considering that the diagnosis of anxiety disorders is delayed by five years on average, even though people suffering anxiety visit the doctor three to six times more often that non-affected people [5]. Despite the high rates of prevalence and the severe discomfort caused by anxiety disorders, less than $25 \%$ of patients receive treatment and often are not treated by specialists.

To a lesser extent, depression has been also associated with JHS. In a recent study using the Hospital Anxiety and Depression Scale, female participants with JHS had higher scores in depression than women without JHS [34]. In addition, the experience of chronic pain has been widely associated with depression [33].

An Italian case-control study [35] revealed that mean scores for the hypermobile group displayed significant psychological distress and an increased frequency and intensity of somatic symptoms. Scores on anxiety and somatic symptoms, general hypochondriasis, disease conviction, affective disturbance, denial, and irritability were significantly higher in the hypermobile than in the healthy group.

Results from a study with undergraduates in France $(\mathrm{N}=365)$, show that scores of somatosensory amplification were higher among participants with JHS independent of gender [34], i.e. they have a significantly greater tendency to amplify somatic sensations interpreting them as intense, noxious, and disturbing. Somatic amplification style is characterised by bodily hypervigilance, a tendency to select and focus on certain relatively infrequent sensations and/or faint, and a propensity to value somatic and visceral sensations as abnormal, pathological and indicative of disease, rather than as normal or benign. Despite JHS having a biological basis for somatic complaints, the perception, recognition and maintenance of JHS symptoms certainly might be influenced by psychological variables such as the tendency to amplify the somatosensory information. 


\section{Problems arising from lack of recognition and knowledge of JHS}

The condition of joint hypermobility was not described as a medical problem until fifty years ago [36] when it was properly identified and associated with various pathologies of the musculoskeletal system. The most used criteria for the diagnosis of JHS was presented only in 1998 by Grahame et al. [38] so it is not surprising that there is still little known about the syndrome.

The lack of information about JHS in the general population and also among health professionals causes a delay in diagnosis. Many of the patients have been suffering from the symptoms for years and feel that their doctors, or even their families, do not understand them [5], or they feel no-one believes them. Grahame [8] reports having the feeling that among his rheumatologist colleagues, people with JHS are often considered to be "neurotic", and labelled as showing a behaviour of desperation. It is difficult for people who suffer from JHS to ask for help for an "unknown state", and not knowing how to explain their condition, often leads to trouble at work or with social security benefit offices. Some patients can even begin to doubt their sanity, having no clear explanation of the cause of their suffering; they can think that the pain might be in their mind [14]. In this setting, patients feel really relieved and grateful to be able to name their illness when they receive the diagnosis, because from there onwards, they can start to take specific initiatives such as seeking information and treatment, explain to others the features of their suffering and gradually to make their condition become socially recognised.

The fact that JHS is considered "benign" is confusing for some patients, because this term emphasises the idea that it is a non-invalidating syndrome, when really for most of them, JHS becomes very disabling. Some authors, such as Bravo [37], do not agree with the nomenclature of Benign Joint Hypermobility Syndrome (BJHS) precisely because such a description minimises the real effects of the syndrome in the lives of many of those affected. This situation helps to increase the feeling patients have that the medical community and society in general do not understand their disorder.

On the contrary, it is a relief for patients to confirm that there is a biological basis for their pain and that it is not a construction of their mind. However, it is important to convey to patients that without doubt, how to deal with the syndrome is determined by psychological variables and in that regard, it is possible to learn some methods to control these psychological factors. 
People with JHS often report feeling alone, marginalised, strange and / or misunderstood. In this regard, psychotherapeutic interventions in a group context and making contact with patient associations are especially useful. This encourages meetings between people with the same syndrome, and through the exchange of experiences, patients can reduce feelings of isolation and increase social and support networks.

The inherited component of JHS and its consequences provoke fear in patients, such as transferring the disease to their children and not being able to cope with the demands of pregnancy and parenthood. In this regard, it is recommendable to move away from precocious therapeutic nihilisms driven by the words "chronicity" or "hereditary disorder", so as not to reinforce these fears and transmit an active attitude towards treatment to the patient [5].

The impact of JHS in patients' families is undeniable. Children of parents affected by JHS may feel anxious or insecure as they perceive the suffering and some degree of disability of their father or mother, as well as a fear that they could suffer from the same problem in the future [19].

These situations show the importance of involving patients' families in the interventions, providing a space for family members to resolve their doubts and fears, and information so that they can understand the complexity of the problem, and adopt an attitude of tolerance, support and cooperation in treatment. Contact with the patients' families also serves to detect dysfunctional dynamics within the family group, which may interfere with the treatment of JHS patients, and also psychological distress in some of its members, which may eventually require individual psychological treatment.

When the affected family member is a child, parents usually require advice about managing the information transmitted to the child about the syndrome, and measures taken with respect to their environment. Gurley-Green [19] reveals some frequent questions posed by parents: Do we tell "the truth" to the child or not?, How to explain the chronicity and the fact that there is no etiological treatment?, What psychological consequences will it have on the child?, Is it necessary to inform the child's school?, May the child use a backpack or do gymnastics?, etc. The lack of information regarding the disease produces disorientation and increases feelings of distress. In this regard, providing a space for listening and psychoeducation to resolve the doubts that arise in everyday life, will enable those affected and their families to reduce negative emotions and prevent inappropriate behavioural patterns such as overprotection, overactivity or underactivity from becoming established, especially 
when the affected family members are children. All these aspects go beyond rheumatology consultation and certainly require psychological counselling.

\section{Conclusion}

JHS is a complex and highly prevalent disorder which requires attention from a biopsychosocial approach. JHS has a heterogeneous presentation including musculoskeletal and psychological symptoms. Symptoms of JHS have a negative impact on the patient's quality of life, and sometimes this may become invalidating.

There are important reasons to consider psychological and psychiatric intervention as part of the overall management of JHS: (1) Chronic pain experience, in which pharmacological treatment and other traditional methods are often ineffective, can be addressed by a cognitive-behavioural therapy tailored to this type of patient. (2) Psychopathological factors associated with JHS, principally anxiety states which are frequent among these patients. Anxiety disorders need to be evaluated and treated with psychotherapy and/or pharmacotherapy. And (3) problematic situations derived from the lack of recognition and knowledge of the syndrome, that can be overcome with psychoeducation programmes and by providing a space for listening and support for both patients and their families. All these aspects should not be underestimated by physicians when establishing an integrated biopsychosocial therapy.

Nowadays, JHS presents several challenges for clinicians and researchers, and it constitutes a broad field for exploration, not only for rheumatologists, but also for mental health professionals. Some of the challenges are: to disseminate information concerning this syndrome among health professionals to improve early detection, and appropriate referral to specialists. The implementation of multidisciplinary teams in medical institutions, with coordinated work among professionals, favouring the integration of knowledge among different specialists. Developing protocols of cognitive-behavioural therapy adapted to the particularity of JHS, such as studies which evaluate the efficacy of these types of intervention among JHS patients. Studies are needed in order to help elucidate the genetic and psychological factors involved in the relationship between anxiety and JHS. 
Developing research in all these areas will enable us to improve our understanding of this syndrome and provide an overall and adapted treatment to improve the quality of life of patients suffering from JHS.

\section{References}

1. Hakim A, Grahame R (2003) Joint Hypermobility. Best Pract Res Clin Rheumatol 17: 9891004.

2. Simpson MR (2006) Bening Joint Hypermobility Syndrome: Evaluation, Diagnosis and Management. J Am Osteopath Assoc 106:531-536.

3. Bulbena A, Duró J, Mateo A, Porta M, Vallejo J (1988) Joint hypermobility syndrome and anxiety disorders (letter). Lancet 17;8612:694.

4. Baeza-Velasco C, Bulbena A (2010) The relationship between anxiety and joint hypermobility: Literature review. Annales Médico Psychologiques 168:263-267.

5. Bulbena A, Benito P, Pailhez G, Gago J, Carbonell J, Sperry L, et al (2004) Hiperlaxitud Articular, definición y exploración. Programa interactivo de formación [Cd rom]. Institut d'Atenció Psiquiàtrica Salud Mental i Toxicomanies Hospital del Mar, Barcelona.

6. Bravo J, Wolff C (2006) Clinical study of hereditary disorders of connective tissues in a Chilean population. Joint hypermobility syndrome and vascular Ehlers-Danlos syndrome. Arthritis Rheum 54:515-523.

7. Gumà M, Olivé A, Holgado S, Casado E, Roca J, Forcada J, et al (2001) Una estimación de la laxitud en la consulta externa. Rev Esp Reumatol 28: 298-300.

8. Grahame R (2003) Hypermobility and hypermobility syndrome. In Keer, R. \& Grahame, R. (Eds.), Hypermobility Syndrome, Recognition and Management for Physiotherapist. (pp. 115). New York; Butterworth Heinemann.

9. Grahame R (2006) Pain, distress and joint hyperlaxity. Joint Bone Spine 67;157-163.

10. Bravo J. Pain in the Joint Hypermobility Syndrome (JHS). [homepage on the Internet]. Available from http://www.reumatologia-dr-bravo.cl/patients/PainJHS.htm)

11. Breivik H, Collet B, Ventafridda V, Cohen R, Gallacher A (2006) Survey of chronic pain in Europe: Prevalence, impact of daily life, and treatment. Eu J Pain 10:287-333.

12. Herrero AM, Ramirez-Maestre C, Gonzalez V (2008) Personality, cognitive appraisal and adjustment in chronic pain patients. Span J Psychol 11: 531-542. 
13. Moix J, Kovacs FM. (2009) Manual del dolor. Tratamiento cognitivo conductual del dolor crónico. Barcelona; Paidos.

14. Harding V, Grahame R (1990) The frequency of joint hypermobility syndrome in chronic pain patients. Pain 5(Suppl):S500.

15. Harding V (2003) Joint hypermobility and chronic pain: possible linking mechanisms and management highlighted by a cognitive-behavioural approach. In Keer R, Grahame R. (Eds.), Hypermobility Syndrome, Recognition and Management for Physiotherapist. New York: Butterworth Heinemann pp.147-161.

16. Keefe FJ (1996) Cognitive behavioral therapy for managing pain. The Clinical Psychologist 49: 4-5.

17. Tison P, Hautekeete M, Bardiaux C, Roussez A (2009) Croyances dans la douleur chronique. Journal de Thérapie Comportementale et Cognitive. 19:67-71.

18. Turk D, Rudy T (1992) Cognitive factors and persistent pain. Cognit Ther Res 16: 99-122.

19. Gurley-Green S (2001) Living with the hypermobility syndrome. Rheumathology 40:487489.

20. López-Espino M, Mingote-Adan JC (2009) El dolor crónico desde la perspectiva psicosomática. C Med Psicosom 89/90:47-57.

21. Chassot P, Piguet V, Remund C, Luthy C, Cedraschi C (2006) Douleurs chroniques et thérapie cognitivo-comportamentale de groupe. Le Courrier de l'algologie 5:7-10.

22. Baeza-Velasco C (2010) Síntoma orgánico vs. Síntoma psicosomático (Editorial). Cuad Neuropsicol 4:8-15.

23. Grahame R (2000) Heritable disorders of connective tissue. Baillieres Best Pract Res Clin Rheumatol 14: 345-361.

24. Ridout K. Management of the joint hypermobility syndrome: anxiety, depression, and chronic pain, in Joint hypermobility syndrome: a complex constellation of symptoms [document on the Internet]. Available from http://www.medscape.com/viewarticle/537938

25. Bulbena A, Gago J, Sperry L, Berge D. (2006) The relationship between frequency and intensity of fears and collagen condition. Depress Anxiety 23: 412-417.

26. Gülsün M, Doruk A, Uzun O, Tonbul M (2006) Eklem hipermobilite sendromu olan klinic disi erkek örnekleminde anksiyete bozukluklari. Yeni Symposium Journal 44:165-168.

27. Gülsün M, Yilmaz MB, Pinar M, Tonbul M, Celik C, Ozdemir B, et al (2007) Thorax deformity, joint hypermobility, and anxiety disorders. Saudi Med J 28:1840-4. 
28. Martín-Santos R, Bulbena A, Porta M, Gago J, Molina L, Duró JC (1998) Association between joint hypermobility syndrome and panic disorder. Am J Psychiatry 155:1578-1583.

29. Baeza-Velasco C, Bulbena A, Bravo JF (2010) Anxious symptomatology and Joint Hypermobility Syndrome (JHS) in a group of Chilean undergraduate students. Ansiedad y Estrés 16:1-12.

30. Gratacòs M, Nadal M, Martín-Santos R, Pujana MA, Gago J, Peral B, et al (2001) A polymorphic genomic duplication on human chromosome 15 is a susceptibility factor for panic and phobic disorders. Cell 106:367-379.

31. Schumacher J, Otte A, Becker T, Sun Y, Wienker T, Wirth B, et al (2003) No evidence for DUP25 in patients with panic disorder using a quantitative real-time PCR approach. Hum Genet 114:115-7.

32. Tabiner M, Youings S, Dennis N, Baldwin D, Buis C, Mayers A, et al (2003) Failure to find DUP25 in patients with anxiety disorders, in control individuals, or in previously reported positive control cell lines. Am J Hum Gen 72: 535-538.

33. Fishbain D, Cutler R, Rosomoff H, Rosomoff R (1997) Chronic pain-associated depression: antecedent or consequence of chronic pain? A review. Clin J Pain 13:116-137.

34. Baeza-Velasco C, Gély-Nargeot MC, Bulbena A, Fénétrier C, Bravo JF (in press) Association between psychopathological factors and joint hypermobility syndrome in a group of undergraduates from a French university. Int J Psychiatr Med.

35. Ercolani M, Galvani M, Franchini C, Baracchini F, Chattat R (2008) Bening joint hypermobility syndrome: psychological features and psychopathological symptoms in a sample pain-free at evaluation. Percep Mot Skills 107:246-256.

36. Kirk JH, Ansell BA, Bywaters EG (1967) The hypermobility syndrome. Ann Rheum Dis 26:419-425.

37. Bravo J. (2008) Significado e importancia de estudiar a las personas con hiperlaxitud articular. Revista Chilena de Reumatología 24:4-5.

38. Grahame R, Bird HA, Child A (2000) The British Society for Rheumatology Special Interest Group on Heritable Disorders of Connective Tissue criteria for the benign joint hypermobility syndrome. The revised (Brighton 1998) criteria for the diagnosis of BJHS. J Rheumatol 27:1777-79. 
